\title{
YOUTUBE AS A MEDIUM FOR INDONESIAN TODDLERS' SECOND LANGUAGE ACQUISITION (AN ANALYSIS THROUGH CHILDREN SONGS)
}

\author{
Yashinta Farahsani ${ }^{1}$, Ika Puspita Rini ${ }^{2}$, Patria Handung Jaya ${ }^{3}$ \\ Department of Mechanical Engineering, Faculty of Engineering, \\ Universitas Muhammadiyah Yogyakarta, Special Region of Yogyakarta, Indonesia ${ }^{1}$, Language \\ Training Center, Universitas Muhammadiyah Yogyakarta ${ }^{23}$
}

yashinta_hime@yahoo.com ${ }^{\text {, azureforphieta@gmail.com², patria.handung@gmail.com³ }}$

\begin{abstract}
Language acquisition for children is started when they produce words on their own. Children's language normally develops in line with their age. Usually, they can produce sentences and speak their mother tongue language fluently at the age of three. At the same time, children are able to acquire another language which is called second language acquisition (SLA). In Indonesia, English has become a second language that has become the main subject at school, from the elementary level to the university level. Toddlers are children in the range of age between 2-3 years. This is the peak time to acquire language, and at this age, children are able to create a phrase or simple sentences. Since technology has developed very rapidly, children also can get more facilities to learn a language. One of the media to learn a language is YouTube. Using the interview method, the writers did an interview with 21 respondents as the parents of pre-school students. There were four questions to answer and the answers were described based on the respondents' opinion. The research results that children can start to learn English through YouTube by watching English songs. Their attraction in watching is followed by imitating the word, the way the characters sing, and also the manner. Parents become a guide to improve the children's process of English learning after they watched YouTube.
\end{abstract}

Keywords: English songs; English learning; language acquisition; toddlers; Youtube

\section{Introduction}

Language acquisition for children is started when they produce words on their own. Children's language normally develops in line with their age. Usually they can produce sentence and speak their mother tongue language fluently at the age of three. In the same time, children are able to acquire other language which is called second language acquisition (SLA). This is the second language that they master after their mother tongue language. Second language acquisition (SLA) focuses on how individuals or groups acquire the language other than their first language. Many experts claim there are two types of SLA; they are informal learning (or subconscious language acquisition (Krashen, 1981)) and formal learning (or 
conscious language learning (Krashen, 1981)). Besides those two, there is also another type of SLA which is the combination of both types (SavilleTroike, 2006. Children are believed to acquire their first language effortlessly and successfully unlike the SLA. It is due to several reasons; one of them is the difference of conceptual development. Children acquire their first language by developing the knowledge of the world and knowledge of language simultaneously (Ellis, 2004). Different from that, SLA is built upon preexisting conceptual knowledge (Ellis, 2004). Besides that, the differences between the acquisition of first and second languages lie in the language input and the transfer.

In Indonesia, English has become a second language that has become the main subject at school, from the elementary level to the university level. It is because English is really needed to communicate because it is the international language. Therefore, besides acquiring the mother tongue languages (the traditional language and Bahasa Indonesia), students also have learned English as the second language and as the foreign language.

Toddlers are children at the range of age between 2-3 years. This is the peak time to acquire language, and at this age, children are able to create phrase or simple sentence.

Sometimes, they can create longer sentence and they also are able to respond what the adult ask. Nowadays toddlers have been able to learn English through some media. Sometimes, parents have taught them at home, or teachers teach them in day care or pre-school. Therefore, it cannot be denied that toddlers are able to speak English in their early age. VanPatten (2004) claimed that "input is necessary for acquisition, defined as the development of an underlying mental representation." However, Gass (2004) argued that interaction is also important in language acquisition since it links the learners' understanding on information and their ability to use it in the development of their second language grammars. Therefore, the balance between the input and output (interaction) should be maintained in second language learning.

Since the technology has developed very rapidly, children also can get more facilities to learn language. One of the media to learn language is YouTube. YouTube is a very attractive social medium that contributes to the global education (Bonk, 2009, Alhamami, 2013). It is being increasingly used by educators to teach the English language (Duffy, 2008, Alhamami, 2013). It "offers fast and fun access to language and culture-based videos and instruction from all over the globe" (Terantino, 2011, p. 11, Alhamami, 2013). From Youtube, children can learn English through stories, songs, or vlogs. However, there is only little research discussing the effectiveness of YouTube in children's language acquisition. So far, a research about YouTube only focuses on its effectiveness for teacher in teaching and learning process and its use for an adult learner.

(Terantino, 2011) wrote an article entitled "YouTube for Foreign Languages: You Have to See This Video". Considering the digital natives, this research focuses on how YouTube can replace the conventional ways in the process of teaching and learning foreign languages. He said that YouTube is 
bridging the gap between what the digital natives want and what the teachers can provide. It is possible because YouTube allows the learners to get fast and fun access to language and cultural-based videos throughout the world. Furthermore, he added that students can actively participate by making their own video to implement the foreign language they have learned into the real situation. Besides its benefit, Terantino also believes that there are several concerns related to the use of YouTube as the tool or media to learn foreign languages-issue of privacy and safety, appropriateness of the videos, and potential problem in accessing the video online. However, these concerns don't come without any solutions. He mentions that we can adjust the setting on YouTube to avoid unexpected things. In addition, he also suggests that learners and teachers can download the videos to avoid the connection problems.

Another research is written by (Watkins \& Wilkins, 2011) entitled "Using YouTube in The EFL Classroom". They believe that online streaming video websites such as YouTube can be very useful in teaching foreign language. YouTube is believed to improve not only one but multiple skills in foreign language such as speaking, listening, reading, and writing. The result of this research shows that teachers can create a speaking and listening activity such as conversation from YouTube because it is served through sight and sound. In the other hand, note-taking and summarizing what the video is about are possible activities to improve learners' writing and reading skills. They can compare their summary to their friends and give suggestions.
The last research related to the use of YouTube to develop language ability was written by (Brook, 2011) entitled "The Affordances of YouTube for Language Learning and Teaching". He believes that YouTube makes it possible for a student-centered learning process. In the discussion, he assigns a project for the students to post a video on YouTube. He provides several lesson plans related to this project and they show that students are more active in the learning process by writing a script for videos, making and editing videos, and commenting on their friends' videos.

From all of the research mentioned before, it is clear that YouTube has an important role in the development of one's language skill or ability. However, the research related to the use of YouTube in toddlers' language acquisition has never been conducted before. Even Brook in his research mentioned that the further research should explore the effectiveness of YouTube in the acquisition of vocabulary. In the end of this research, the writers will show that YouTube is not only able to improve the skills in language but it is also able to help toddler in acquiring the language through the exposure of vocabulary. In this case, the exposure of the vocabulary will be obtained from the English children songs.

This topic is very interesting to discuss, so the writers want to discuss about the way children songs on YouTube can be a media to acquire children's second language. This paper focuses on English as the second language. The writers predict that children songs on YouTube can be great 


\section{p-ISSN 1412-9418 e-ISSN 2502-5783 \\ Humanika Vol. 27 no 2 Copyright @2020 \\ Available online di http://ejournal.undip.ac.id/index.php/humanika}

media for toddlers in acquiring English as their second language.

\section{Research method}

This study is a qualitative descriptive research. The research subject was toddlers or children at the age between 25 years old, while the object of the research was the children's habit toward YouTube as a media to learn language. The techniques of data collection were interview and library research. The respondents for the interview were 21 parents who have toddlers or children at the age between $2-5$ years old. The writers asked some questions about the children's attention on YouTube and YouTube as a media to learn language, especially English. Data taken from library research served as secondary data to support the primary data taken from the interview.

After the data were collected both from interview and library research, the data were analyzed qualitatively. After the analysis, the data are identified and classified to answer the research questions. The instruments of data collection and analysis were notes, laptop, and the researchers themselves as human instrument.

\section{Results and Discussion}

\section{Interview Findings}

We provided four questions to be answered by parents to see the children's familiarity and their attraction of YouTube. Besides, the result of the interview also show hoe YouTube can be used as a medium to learn English by the toddlers.
Question 1. Is your child familiar with YouTube?

From 21 respondents, 15 people answered that their children are familiar with YouTube. It is Children report valuing the platform for its choice and frequent renewal of video content. Children are frequent viewers of YouTube video bloggers (YouTubers), individuals who create and share videos on YouTube, and view this content as a source of entertainment (Coates: 2020). We could not deny that nowadays, YouTube has attracted, not only the adults, but also the children. With their usage in using cellphone, usually their parents' cellphones, they can browse the YouTube channels and open some videos. From the research result, most of parents admit that their children are familiar with YouTube. With their age, around 2-5 years old, they even can operate the cellphone by themselves.

While the rest of 6 respondents, they said that their children are not familiar with YouTube because some children have lack of curiosity of YouTube, so they are not interested in accessing that platform. They prefer to play with other toys, but not cellphone.

From the respondents' statements, we can conclude that the children's familiarity on YouTube depends on their interest in it. If they are interested, then they will access and enjoy the platform.

Question 2. Does your child have an attraction to learn something from YouTube?

Started from the attraction in the platform content, children can learn many things from that unconsciously. Based on the interview result, 15 parents said that 
their children are attracted to learn something using YouTube.

YouTube has been serving many contents that can be enjoyed by the viewers. Of course, parents must filter what their children can watch, and what cannot. Most parents serve the children by showing them children stories, songs, or cartoon movies from YouTube both in bahasa Indonesia and English. It can be one way to learn, not only language but also the other things. However, learning from YouTube can improve children's ability in speaking, both their mother tongue language and English. What they watch can be imitated by them. Sometimes, they can imitate the words, or the songs. By imitating them, the children are learning the language.

While the rest of 6 respondents, the children are not attracted to learn something from YouTube, and it is correlated to the question 1 . They said that children can learn many things not only from YouTube, but also from their environment.

From the respondents' statement, we can conclude that many children are attracted to learn something from YouTube and parents can take the positive benefit that YouTube can be a medium to learn.

Question 3. What kinds of video that the children prefer to watch in YouTube?

Most of the parents answer this questions by saying that the children like to watch songs both in English and Bahasa Indonesia. At their age, they can imitate the song lyric and also they can dance. The songs can be memorized well and the children can sing the song anytime even they are not at the moment of browsing YouTube.

Question 4. Are the children attracted to learn English from YouTube?

The attraction in learning English via YouTube is something unavoidable when children get used with it. It serves many contents that can be choosen by the viewers. Youtube also creates Youtube kids as a children friendly application. There, the children can enjoy the videos that are appropriate with their age, because Youtube has filtered the content. Youtube kids serves many videos as media to learn language. There are many kids channels that can be alternative for the children. Some parents mentioned Cocomelon and Babybus are the most favorite ones. These videos contains children songs that are easy listening and very interesting to watch. Besides listening to the songs, the children also imitate what the characters' doing. Therefore, setting the characters becomes very important factor to attract the viewers.

Children are good imitators, who can imitate what other people do or say. Just like when they watch the video and enjoy it. They do not only watch the video, but they also try to get the idea about the video. After that, they start to imitate, for example try to sing the song, say the words from the song, or dance as the characters to in the song.

a. Memorizing numbers and alphabets

By watching the video about numbers and alphabet songs, children can learn 
the order of the numbers and the alphabets, and also they can pronounce the number and the letter correctly.

\section{b. Memorizing the words or vocabulary}

By watching the video, children can memorize the words that are mentions in the songs, for example from "the ice cream song", children can memorize some vocabulary there, such as ice cream, vanilla, chocolate, strawberry, flavor, etc. Besides, the Youtube videos can help them to memorize the daily things, such as animals, fruits, vegetables, jobs, seasons, atc.

\section{c. Singing and dancing}

For the children with the age above 3, usually they start to love singing. By watching Youtube video, they can sing as what the video shows.

\section{d. Manners}

The videos make the children learn how to take a bath, how to wash their teeth, or even the manners to say good words such as thank you, sorry, and excuse me.

\section{Discussion}

From the findings above, there are some important points that are interesting to discuss. First, children are easily attracted by something that they think it is interesting. Since now, many children are familiar with cellphone and internet, parents should be able to control and facilitate their children in the process of learning. YouTube as one of the learning media should be filtered, so the children can enjoy the video safely.

Second, the children's attraction in YouTube should be responded positively. Therefore, parents should guide them, so the children can enjoy the process of learning. When the children have memorized many vocabulary, numbers, and even have been able to sing, parents can have a role to help them improve what they have learned from YouTube. From here, we can say that YouTube is the medium to start learning, then the process is continued by the parents.

\section{Conclusion}

Language acquisition for children is started when they produce words on their own. Children's language normally develop in line with their age. In Indonesia, English has become a second language that has become the main subject at school, from the elementary level to the university level. It is because English is really needed to communicate because it is the international language. Therefore, besides acquiring the mother tongue languages (the traditional language and bahasa Indonesia), children also have to learn English as the second language and as the foreign language. Since the technology has developed very rapidly, children also can get more facilities to learn language.

The result demonstrates that YouTube can be a medium to learn English by the toddlers. With their characteristic to be easily attracted by the current technology, toddlers are attracted to learn something, not only language, through 
Youtube. From the research results, it concluded that children can learn English language, such as memorizing numbers, alphabets, daily vocabulary, singing, and manners. That is the start that should be improved by the guidance of the parents.

\section{References}

Alhamami, Munassir. (2013). Observation of Youtube Language Learning Videos (Youtube LLVS). Teaching English with Technology, 13(3), 3-17

Alkathiri, L. A. (2019). Students' Perspectives towards Using YouTube in Improving EFL Learners' Motivation to Speak. Journal of Education and Culture Studies, 3(1), 12-30. Retrieved from www.scholink.org/ojs/index.php/jec $\underline{s}$

Anderson, J. (2013). Individualisation of higher education: How technological evolution can revolutionise opportunities for teaching and learning. International Social Science Journal, 64 (213-214), 305-316. https://doi.org/10.1111/issj.12046

Bonk, C. (2009). The World is Open: How Web Technology is Revolutionizing Education. San Francisco: JosseyBass

Brook, J. (2011). The Affordances of YouTube for Language Learning and Teaching Jennifer Brook What is YouTube? Hawaii Pacific University TESOL Working Paper Series, 9(1,2), 37-56.

Anna Elizabeth Coates, C. A. (2020). "It's Just Addictive People That Make Addictive Videos": Children's Understanding of and Attitudes towards Influencer Marketing of Food and Beverages by YouTube Video Bloggers. International Journal of Enviromental Research and Public
Health, $\quad$ 17(449), 2-18. doi:10.3390/ijerph17020449

Duffy, P. (2008). Engaging the YouTube Google-eyed generation: Strategies for using Web 2.0 in teaching and learning. The Electronic Journal of eLearning, 6, 119-130. Retrieved from http://www.ejel.org/volume6/issue 2/p119

Ellis, N. C. (2004). The processes of second language acquisition. In VanPatten, B., Williams, J., Rott, S. \& Overstreet, M. (Eds.), Form-meaning connections in second language acquisitions (pp. 49-76). New Jersey: Lawrence Erlbaum Associates, Inc.

Ellis, R. (1994). The study of second language acquisition. Oxford University.

Gass, S. M. (2004). Context and second language acquisition. In VanPatten, B., Williams, J., Rott, S. \& Overstreet, M. (Eds.), Form-meaning connections in second language acquisitions (pp. 77-90). New Jersey: Lawrence Erlbaum Associates, Inc.

Gayatri, G., Rusadi, U., Meiningsih, S., Mahmudah, D., Sari, D., Kautsarina, ... Nugroho, A. C. (2015). Digital citizenship safety among children and adolescents in indonesia. Jurnal Penelitian dan Pengembangan Komunikasi dan Informatika, 6(1), 1-18.

Imaniah, I., Dewi, N. F., \& Zakky, A. (2020). Youtube kids channels in developing young children's communication skills in english: parents' beliefs, attitudes, and behaviors. International Journal of Language Education and Cultural Review, 6(1), 20-30. Retrieved from http://journal.unj.ac.id/unj/index.ph p/ijlecr 
Krashen, S. D. (1981). Second language acquisition and second language

Li, Z. H. O. U. (2015). Can Adults Attain a Native-Like Accent in Their Second Language? Sino-US English Teaching, 12(6), 403-409.

Rahman, Muhammad Mosiur, Ambigapathy Pandian, Abdul Karim \& Faheem Hasan Shahed. (2017). Effect of Age in Second Language Acquisition: A Critical Review from the Perspective of Critical Period Hypothesis and Ultimate Attainment. International Journal of English Linguistics; 7(5).

Saville-Troike, M. (2006). Introducing second language acquisition. Cambridge: Cambridge University Press learning. Oxford: Pergamon Press, Inc.

Terantino, J. M. (2011). Emerging technologies YouTube for foreign languages: You have to see this video. Language Learning and Technology, 15(1), 10-16.

VanPatten, B. (2004). Input and output in establishing form-meaning connections. In VanPatten, B., Williams, J., Rott, S. \& Overstreet, M. (Eds.), Form-meaning connections in second language acquisitions ( $\mathrm{pp}$. 29-48). New Jersey: Lawrence Erlbaum Associates, Inc.

Watkins, J., \& Wilkins, M. (2011). Using YouTube in the EFL Classroom. 2(1), 113-119. 